\title{
Effects of cooking methods and new cultivars on physico-chemical properties of potatoes
}

\section{Cemal Kasnak, Recep Palamutoğlu}

\section{Afyonkarahisar Health Sciences University, Afyonkarahisar, Turkey}

Keywords:

Antioxidant

Potato

Cooking

Texture

Total phenolics

\section{Article history:}

Received

19.02.2021

Received in revised form 21.04.2021

Accepted

16.07.2021

\section{Corresponding author:}

Recep Palamutoğlu E-mail: receppalamutoglu@ hotmail.com

DOI:

$10.24263 / 2310-$

1008-2021-9-1-7

\section{Abstract}

Introduction. The aim of the study was to investigate the effects of cooking methods, i.e., boiling, pan frying, deep frying on total phenolic content (TPC), antioxidant activity \% (AA) with DPPH (2,2-Diphenyl-1-picrylhydrazyl), trolox equivalent (TEAC), 2 2'azino-bis(3-ethylbenzothiazoline-6-sulphonic acid) (ABTS), ferric ion reducing antioxidant parameter (FRAP), color and texture profile analysis (TPA) in five new cultivars (Fatih, Nahita, Nam, Onaran and Ünlenen) of Turkey.

Materials and methods. For analysis potatoes were used by fresh, and cooked by three different methods such as boiling (in soaked in cold water and boiled for 30 minutes), frying (Deep fried in corn oil in a large pan) and baking (at $220{ }^{\circ} \mathrm{C}$ for 45 minutes). TPC, AA with DPPH, TEAC, FRAP were determined by spectrophotmetric methods, texture parameters were determined by the texture analyser TA.HDplus and color was determined by a colorimeter.

Results and discussion. There were no significant $(p>0.05)$ differences found between the TEAC, AA, ABTS and FRAP, values of the different potato cultivars. The effects of cooking methods on TPC, TEAC, AA, ABTS, FRAP, color and TPA were significantly different $(p<0.01)$. The highest phenolic contents, TEAC, AA, ABTS, FRAP results were found in the pan fried samples $932,23 \pm 114,82 \mathrm{mg}$ catechin $/ \mathrm{kg}$ potato, $331.00 \pm 23.42 \mu \mathrm{g}$ Trolox $/ \mathrm{g}$ potato, $81.75 \pm 7.46 \%, \quad 1830.60 \pm 961.66 \mu \mathrm{g}$ Trolox/g potato, $6115.00 \pm 2164.91 \mu \mathrm{g}$ Trolox/g potato respectively. Fresh and deep fried potatoes have the highest $L^{*}$ values $(75.68 \pm 0.69,72.33 \pm 3.12$ respectively) and pan fried samples has the lowest $L^{*}$ values $(64.31 \pm 10.16)$. The lowest $a^{*}$ values observed at boiled samples ($3.92 \pm 1.59)$ and the highest was the pan fried samples $(1.31 \pm 4.98)$. There was no significant $(\mathrm{p}>0.05)$ differences about texture profile parameters between the 5 different cultivars of potato. Texture profile analysis results of cultivars were, Hardness (1633.592065.92), Adhesiveness (-81.42-54.74), Springiness (1.83-4.06), Cohesiveness (0.68-0.80), Gumminess (995.17-1188.32), Chewiness (1410.36-2173.34), and Resilience (0.68-0.83).

Conclusions. TPC and antioxidant activities of pan fried samples are significantly higher from other cooking methods. The results may also help consumers for choosing the cooking method for health promoting compounds to human use. There is a need for further researches about the bio availability of nutrients from different parts of potatoes and new cultivars. 


\section{Introduction}

Potatoes are consumed as a basic food in many countries of the world and are characterized by a high content of sugar, protein and vitamin $\mathrm{C}$ content. Fresh potatoes contain about $20 \%$ dry matter and $60-80 \%$ of this dry matter is starch. This makes them a good source of energy. Potatoes are weak in terms of fat content, but rich in vitamins such as $\mathrm{B} 1$, B3, B5, B6, B9, riboflavin, and minerals such as $\mathrm{K}, \mathrm{P}$ and $\mathrm{Mg}$ [1]. Potato is an important food crop and it contains a wide variety of phytochemicals such as phenolic compounds, and these compounds are affected by several factors [2,3]. Due to their bioactivity, phenolics have beneficial effects on human wellness. These bioactive substances can be affected by processing conditions, cooking methods [3]. Palermo and co-workers [4] reviewed the effect of cooking conditions on the phytochemicals by two opposite opinions. One of the ideas is that as a result of thermal degradation, the concentration of these phytochemicals decreases, and the other is the softening of the matrix that acts to increase the extractability of phytochemicals.

The aim of the study was to determine and determine the effect of boiling, frying, roasting on TPC and DPPH, ABTS, FRAP, texture profile parameters of new cultivated five potato varieties (Fatih, Nahita, Nam, Onaran, Ünlenen) in Turkey.

\section{Materials and methods}

Catechin, 2,2-diphenyl-1-1 picrylhydrazyl (DPPH), potassium persulfate, 2,2'azinobis,-(3-tehyl-benzothiazoline-6-sulfonic acid), Folin-Ciocalteu phenol reagent, 2,4,6Tris(2-pyridyl)-s-triazine(TPTZ), methanol were purchased from Sigma.

\section{Sampling of potato tubers}

The tubers of Fatih, Nahita, Nam, Onaran and Ünlenen (newly registered varieties) potato varieties were obtained from Potato Research Institute Niğde/Turkey. For further analysis potatoes were used by fresh, and cooked by three different methods such as boiling (in soaked in cold water and boiled for 30 minutes), frying (Deep fried in corn oil in a large pan) and baking (at $220{ }^{\circ} \mathrm{C}$ for 45 minutes). Two uniform tubers selected and used for cooking. Home type cooker and oven were used for cooking (OI636 cooktop and $9620 \mathrm{MI}$ oven, Arçelik/Turkey). For further analysis potato samples were used after grinding. The analyzes were carried out in duplicate.

\section{Proximate analysis}

Average weight of tubers were found by weighting 4 uniform tubers of potatoes.

\section{Extraction of potato samples}

Phenolic isolation of samples was done by the method of Shahidi and co-workers [5]. According to this method one gram sample extracted with methanol $(70 \% ; 10 \mathrm{ml})$ for 3 times using a homogenizer (11.000 rpm;1 $\mathrm{min}$ ) (Daihan HG-15D). Then the slurry centrifuged at $4000 \mathrm{rpm}$ for $15 \mathrm{~min}$. Methanolic phase was collected and evaporated by rotary evaporator (Scilogex-RE100) at $45^{\circ} \mathrm{C}$ under vacuum. Methanol $(25 \mathrm{ml}$ ) was added to the extracted phenolics and filtered by filter paper (Whatmann No:1). Extractions and all analysis given below were performed in 2 replicates. 


\section{Determination of total phenolic content}

The TPC was determined according to Kaur and Kapoor [6]. Methanolic extract, distilled water and Folin Ciocalteu reagent $(0.5: 7: 0.5 \mathrm{ml})$ were added to test tube and mixed for $3 \mathrm{~min}$. Then sodium carbonate $(20 \%, 2 \mathrm{ml})$ was added and mixed again. The solutions were kept in water bath for 1 hour at $25^{\circ} \mathrm{C}$ and then read at $720 \mathrm{~nm}$. Results were expressed as $\mathrm{mg}$ catechin of fresh weight potato using a standard calibration curve of catechin $(r>0.99)$.

\section{Scavenging of DPPH radical}

The method of Kasnak [7] was used for determining the scavenging of DPPH radical. The methanolic DPPH $(0,4 \mathrm{ml}, 96 \mathrm{mg} / \mathrm{L})$ and $1,6 \mathrm{ml}$ of sample was mixed and left for dark for $30 \mathrm{~min}$ at room temperature. The absorbance was measured at517 nm against the blank. The results were shown as Trolox equivalent (mg TE/g fresh potato) through the calibration curve $(r>0.99)$. below;

Also antioxidant activiy (AA) (\%) was calculated according to the equation given

Antioxidant activity $(\%)=\left[\left(\mathrm{A}_{\text {blank }}-\mathrm{A}_{\text {sample }}\right) / \mathrm{A}_{\text {blank }}\right] \times 100$

\section{Scavenging of ABTS}

Analysis of $\mathrm{ABTS}^{++}$radical scavenging activity was determined by the method of Re and co-workers [8] modified by Kasnak [7]. The absorbance of ABTS solution was set to $0.70 \pm 0.02$ at $732 \mathrm{~nm}$ with methanol before analysis. The ABTS solution $(990 \mu \mathrm{l})$ and the extract $(10 \mu \mathrm{l})$ mixed and left for $30 \mathrm{~min}$ for incubation. The results were given as Tolox equivalent $(r>0.99)$.

\section{Ferric reducing power (FRAP) assay}

Ferric reducing assay was performed by Benzie and Strain [9] method with slight modification. The FRAP reagent was freshly prepared by mixing acetate buffer, TPTZ solution, $\mathrm{FeCl}_{3} \cdot 6 \mathrm{H}_{2} \mathrm{O}$ in a ratio of $10: 1: 1$ and adding $12 \mathrm{~mL}$ distilled water, at $37^{\circ} \mathrm{C}$. The FRAP reagent: deionized water: extract/standard or blank were mixed (1.8: 0.18: $0.06 \mathrm{~mL}$ ) in the same test tubes, and incubated at $37^{\circ} \mathrm{C}$ for $4 \mathrm{~min}$; absorbance was read at $593 \mathrm{~nm}$. The results were given as Tolox equivalent $(\mathrm{r}>0.99)$.

\section{Color measurement}

The color attributes of potato samples were measured by Ci64 (X-rite/USA). The color was expressed in $\mathrm{L}^{*} \mathrm{a} * \mathrm{~b}$. Color parameters were measured against a white calibration plate and were directly obtained from the apparatus.

\section{Texture profile analysis of potatoes}

Texture of fresh and cooked potatoes was evaluated by subjecting each sample to a compression test using texture analyser TA.HDplus (Stable Micro Systems/UK) equipped with a $50 \mathrm{~N}$ load cell. A flat plate $(50 \mathrm{~mm}$ diameter) was used at a cross-head speed of 50 $\operatorname{mmmin}^{-1}[10]$. 


\section{Statistical analysis}

Statistical analysis of all data was performed using the software program SPSS (version 18.0). Multiple comparisons were done with Tukey's test.

\section{Results and discussion}

\section{Total phenolic content}

The TPC of fresh, boiled, pan fried and deep fried potatoes and potato cultivars are given in Figure 1.

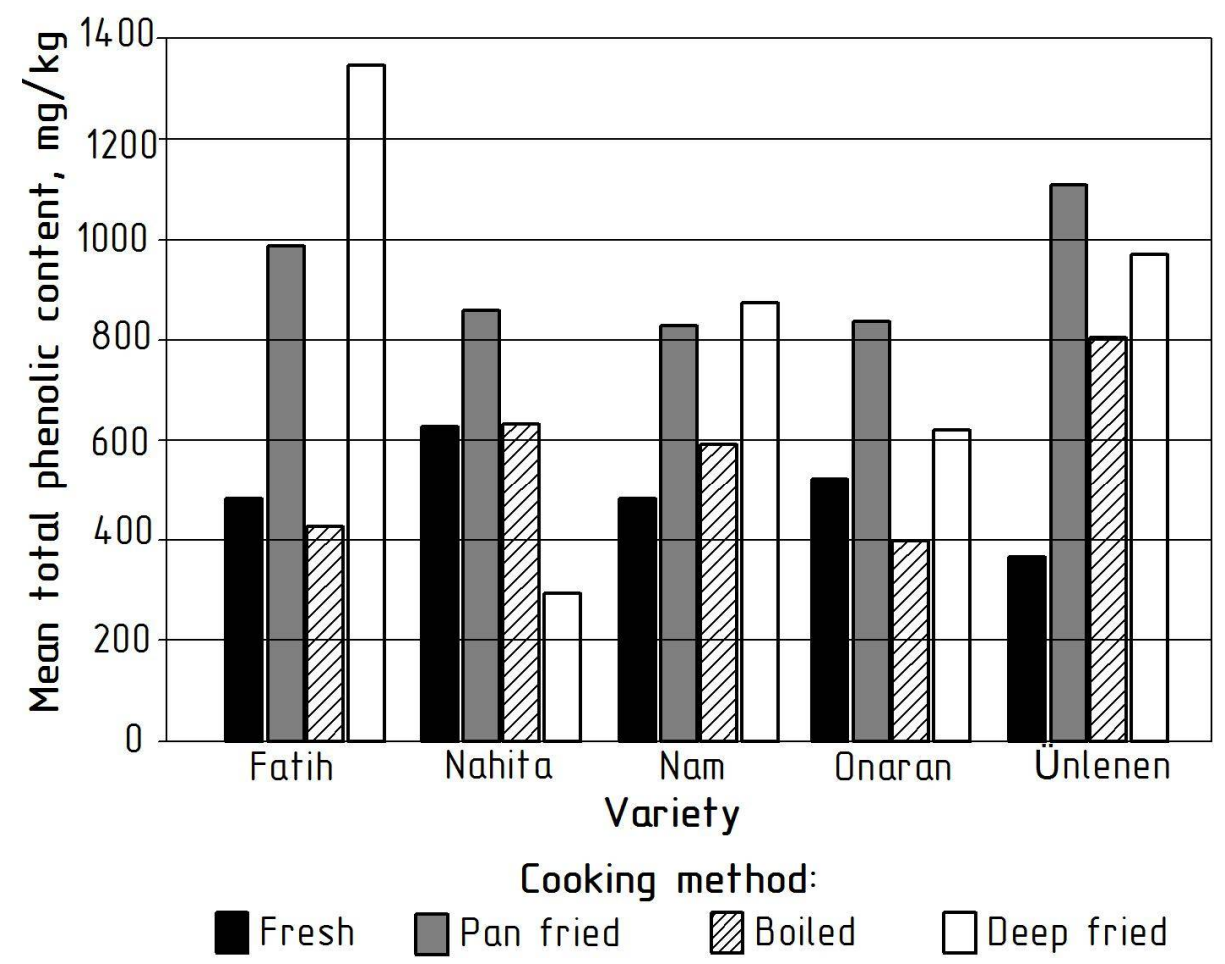

Figure 1. Total phenolic content (means \pm SD) of potato cultivars cooked with different methods

The highest TPC was found in the pan fried samples $(932,23 \pm 114,82 \mathrm{mg}$ catechin $/ \mathrm{kg}$ potato) and were significantly different from fresh and boiled samples. The lowest TPC of the samples was found in fresh potatoes $(500,93 \pm 90,68 \mathrm{mg}$ catechin $/ \mathrm{kg}$ potato). There was no significant difference $(\mathrm{p}>0.05)$ were found between the potato cultivars TPC. The TPC of potato varieties vary from $604,50 \pm 173,61$ to $819,46 \pm 302,74 \mathrm{mg}$ catechin $/ \mathrm{kg}$ potato. Figure 1 shows the TPC of potato cultivars cooked by different methods. Kaur and Kapoor [6] reported the phenolic content of potato $149,8 \pm 6.3 \mathrm{mg}$ catechol/100 $\mathrm{g}$ sample, also Karadeniz and co-workers [11] found $553 \pm 102.5 \mathrm{mg}$ catechin $/ \mathrm{kg}$ fresh weight. Lachman and coworkers [12] found significant differences in TPC between yellow (2.46-3.44 g/ $/ \mathrm{kg} \mathrm{dm})$ and 
purple (4.55-4.81 g/kg dm) fleshed cultivars and also between yellow fleshed cultivars. Perla and co-workers [13] concluded that the lowest phenolic content of potato tubers was Russet Nugget $(0.9 \mathrm{mg} / \mathrm{g})$ and other tubers phenolic contents ranged between 1.2 and $1.9 \mathrm{mg} / \mathrm{g}$. Also, they said that all the cooking methods reduced the TPC in all cultivars tested. However, Blessington and co-workers [14] reported an increase in TPC when tubers were baked, microwaved and fried, and no loss when boiled. They concluded that improving the extractability of phenolic compounds from the cellular matrix of cooked samples is responsible for this increase.

\section{Antioxidant analysis results}

According to antioxidant activity analysis results there were no significant differences $(p>0.05)$ were found between the potato cultivars in the meaning of TEAC, AA, ABTS and FRAP. However, there were significant differences $(\mathrm{p}<0.01)$ were found between fresh and cooked potato results. Rumbaoa and co-workers [15] reported methanolic extracts of potatoes have significant antioxidant activity and also reported a correlation between total phenolic content and DPPH radical scavenging activity. This indicates the phenolic compounds are responsible for the antioxidant activity. The same judgment has been given by Bellumori et al. [16] for TPC and ABTS values. Deng and co-workers [18] concluded that the thermal processing significantly increases the TPC and antioxidant capacities (DPPH, ABTS).

Pan fried samples have the highest amounts of TEAC, AA, ABTS and FRAP values. TEAC results showed that minimum values of Trolox equivalent antioxidant capacities antioxidant activity were in fresh group $(254.35 \pm 38,04 \mu \mathrm{g}$ Trolox/g potato). All of the cooking methods significantly $(p<0.01)$ increase the TEAC. But there are not significant differences found among the cooking methods. Pan fried samples showed the highest TEAC (331.00 $\pm 23,42 \mu \mathrm{g}$ Trolox/g potato). Table 1 shows the antioxidant activities of potato cultivars cooked by different methods.

Table 1

Effects of variety and cooking methods on antioxidant activities of potato tubers

\begin{tabular}{|l|c|c|c|c|}
\hline & $\begin{array}{c}\text { TEAC } \\
\mu \text { T Trolox/g } \\
\text { potato }\end{array}$ & $\begin{array}{c}\text { AA } \\
\mathbf{( \% )}\end{array}$ & $\begin{array}{c}\text { ABTS } \\
\mu \text { Tg Trolox/g } \\
\text { potato }\end{array}$ & $\begin{array}{c}\text { FRAP } \\
\mu \text { Trolox/g } \\
\text { potato }\end{array}$ \\
\hline \multicolumn{5}{|c|}{ Varieties } \\
\hline Fatih & $317,38 \pm 30,39$ & $76,95 \pm 10,45$ & $1101,25 \pm 596,86$ & $3712,50 \pm 2062,63$ \\
\hline Nahita & $308,25 \pm 45,41$ & $75,57 \pm 12,49$ & $734,00 \pm 245,15$ & $2875,00 \pm 823,54$ \\
\hline Nam & $290,00 \pm 45,87$ & $67,29 \pm 16,00$ & $800,75 \pm 240,98$ & $2387,50 \pm 926,69$ \\
\hline Onaran & $275,63 \pm 47,08$ & $62,06 \pm 16,52$ & $861,25 \pm 685,64$ & $2781,25 \pm 2579,34$ \\
\hline Ünlenen & $321,13 \pm 33,04$ & $78,20 \pm 11,46$ & $1509,50 \pm 1219,17$ & $4587,50 \pm 2972,04$ \\
\hline \multicolumn{5}{|c|}{ Cooking method $^{\mid}$} \\
\hline Fresh & $254.35 \pm 38,04^{\mathrm{b}}$ & $56.31 \pm 13.25^{\mathrm{b}}$ & $411.20 \pm 60.41^{\mathrm{b}}$ & $2090.00 \pm 521.11^{\mathrm{b}}$ \\
\hline Pan fried & $331.00 \pm 23,42^{\mathrm{a}}$ & $81.75 \pm 7.46^{\mathrm{a}}$ & $1830.60 \pm 961.66^{\mathrm{a}}$ & $6115.00 \pm 2164.91^{\mathrm{a}}$ \\
\hline Boiled & $306.10 \pm 37,56^{\mathrm{a}}$ & $73.01 \pm 13.14^{\mathrm{a}}$ & $798.40 \pm 246.31^{\mathrm{b}}$ & $2025.00 \pm 769.92^{\mathrm{b}}$ \\
\hline Deep fried & $318.45 \pm 25,78^{\mathrm{a}}$ & $76.98 \pm 9.11^{\mathrm{a}}$ & $965.20 \pm 241.79^{\mathrm{b}}$ & $2845.00 \pm 1137.91^{\mathrm{b}}$ \\
\hline
\end{tabular}

Data are expressed as means $\pm \mathrm{SD}(\mathrm{n}=2)$. Values in each column having different letter are significantly different $(\mathrm{p}<0.01)$ 
Table 2

Correlation between cooking method, total phenolic content and antioxidant activities

\begin{tabular}{|l|l|l|l|c|}
\hline & TEAC & AA\% & ABTS & FRAP \\
\hline Cooking method & $0,445^{* *}$ & $0,420^{* *}$ & $0,099^{\text {ns }}$ & $-0,098^{\text {ns }}$ \\
\hline Total phenolic content & $0,539^{* *}$ & $0,547^{* *}$ & $0,653^{* *}$ & $0,681^{* *}$ \\
\hline
\end{tabular}

**; Significant at 0.01 level,*; Significant at 0.05 level ns; Not Significant

Results show similarity with Blessington and co-workers [14] researches and they showed the antioxidant activity increase in the cooked samples of potato and they suggested that extractability of the antioxidant and phenolic compounds from the cellular matrix of cooked samples are responsible for this increase. The AA of fresh $(56.31 \pm 13.25)$ potato samples were significantly $(\mathrm{p}<0.01)$ lower than the other cooked $(73.01 \pm 13.14 \%$ to $81.75 \pm 7.46 \%$ ) potatoes. And there was no significant difference were found between the cooked samples. Bellail and co-workers [17] indicated an increase in the DPPH values of sweet potato root tissues cooked with different processing methods. They also reported thermal processing, increased the ABTS values more than DPPH. ABTS results showed that the pan fried potatoes were significantly higher $(p<0.01)$ than fresh and other cooked samples. FRAP results were similar to ABTS results.

Deng and co-workers [18] found FRAP, TEAC values and TPC of potatoes $10.85 \pm 0.77 \mu \mathrm{mol} \mathrm{Fe}(\mathrm{II}) / \mathrm{g}$ fresh weight, $8.33 \pm 0.15 \mu \mathrm{mol}$ Trolox $/ \mathrm{g}$ fresh weight and $7.16 \pm 0.05$ $\mathrm{mg}$ Gallic acid equevalent /g fresh weight.

\section{Colour measurements}

Color parameters of potato varieties and cooked potatoes were given in Table 3. Color is the main parameter for consumer judges to buy food products. There was no significant difference were seen between the varieties in the manner of lightness and redness values. The highest $b$ value was found at Fatih cultivar and there were no significant differences were seen with Nam and Ünlenen. And also there was no significant differencess were found between Nahita, Nam, Onaran and Ünlenen cultivars.

Table 3

Effects of variety and cooking methods on colour parameters of potato tubers

\begin{tabular}{|l|c|c|c|}
\hline & $\mathbf{L}^{*}$ & $\mathbf{a}^{*}$ & $\mathbf{b}^{*}$ \\
\hline Varieties & & & $32,46 \pm 6,14^{\mathrm{a}}$ \\
\hline Fatih & $68,80 \pm 5,70$ & $0,08 \pm 3,54$ & $21,43 \pm 8,94^{\mathrm{b}}$ \\
\hline Nahita & $68,25 \pm 6,29$ & $-3,42 \pm 1,70$ & $27,05 \pm 9,44^{\mathrm{a}, \mathrm{b}}$ \\
\hline Nam & $74,72 \pm 5,24$ & $-0,91 \pm 4,49$ & $20,60 \pm 2,95^{\mathrm{b}}$ \\
\hline Onaran & $68,52 \pm 10,48$ & $-1,60 \pm 3,44$ & $27,95 \pm 3,14^{\mathrm{a}, \mathrm{b}}$ \\
\hline Ünlenen & $70,10 \pm 6,51$ & $-0,35 \pm 3,29$ & \\
\hline Cooking method & & & $32.47 \pm 5.35^{\mathrm{a}}$ \\
\hline Fresh & $75.68 \pm 0.69^{\mathrm{a}}$ & $-1.57 \pm 0.30^{\mathrm{a}, \mathrm{b}}$ & $26.14 \pm 8.16^{\mathrm{a}, \mathrm{b}}$ \\
\hline Pan fried & $64.31 \pm 10.16^{\mathrm{c}}$ & $1.31 \pm 4.98^{\mathrm{a}}$ & $19.13 \pm 7.05^{\mathrm{b}}$ \\
\hline Boiled & $68.00 \pm 5.09^{\mathrm{b}, \mathrm{c}}$ & $-3.92 \pm 1.59^{\mathrm{b}}$ & $25.85 \pm 4.17^{\mathrm{a}, \mathrm{b}}$ \\
\hline Deep fried & $72.33 \pm 3.12^{\mathrm{a}, \mathrm{b}}$ & $-0.77 \pm 3.01^{\mathrm{a}, \mathrm{b}}$ & \\
\hline
\end{tabular}

Data are expressed as means \pm SD $(n=2)$. Values in each column having different letter are significantly different $(\mathrm{p}<0,01)$ 
Fresh and deep fried potatoes have the highest $L^{*}$ values and pan fried samples has the lowest $L^{*}$ values. The lowest $a^{*}$ values observed at boiled samples and the highest were the other samples. Fresh samples have the highest $b$ values and there was no significant difference were found between pan and deep fried samples. Also, there was no significant difference were found between boiling, deep and pan fried samples. Singh and co-workers [19] reported the $L^{*}, a^{*}, b^{*}$ parameters of six varieties differs significantly. These parameters range between 68.6-73.9, -1.7- -2.8 and 21.5-28.6 respectively. According to Nourian and co-workers [10] $\mathrm{L}^{*}$ value of boiled potato decreased and no major changes observed at $a^{*}$ and $b^{*}$ values. Pedreschi and co-workers [20] results did not show any changes in the manner of $L^{*}$ and $b^{*}$ values of potao chips, but at a values there was a progressive increase were seen with frying time.

Table 4 shows there was no significant differences about texture profile parameters (Hardness, Adhesiveness, Springiness, Cohesiveness, Gumminess, Chewiness, Resilience) between the 5 different cultivars of potato.

Table 4

Effects of variety and cooking methods on texture profile parameters of potato tubers

\begin{tabular}{|c|c|c|c|c|c|c|c|}
\hline & 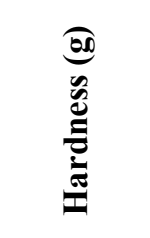 & 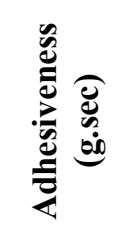 & 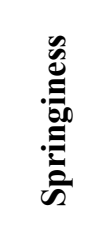 & 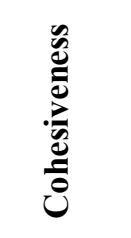 & 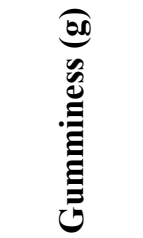 & 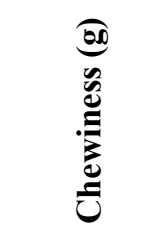 & 递 \\
\hline \multicolumn{8}{|l|}{ Varieties } \\
\hline Fatih & $\begin{array}{c}1901,16 \\
\pm 1448,05\end{array}$ & $\begin{array}{l}-60,34 \\
\pm 67,59\end{array}$ & $\begin{array}{c}2,84 \\
\pm 2,79\end{array}$ & $\begin{array}{c}0,72 \\
\pm 0,12\end{array}$ & $\begin{array}{l}1188,32 \\
\pm 700,51\end{array}$ & $\begin{array}{l}1493,42 \\
\pm 499,73\end{array}$ & $\begin{array}{c}0,74 \\
\pm 0,33\end{array}$ \\
\hline Nahita & $\begin{array}{c}2065,92 \\
\pm 2021,11\end{array}$ & $\begin{array}{l}-65,69 \\
\pm 74,21\end{array}$ & $\begin{array}{c}2,36 \\
\pm 2,05\end{array}$ & $\begin{array}{c}0,68 \\
\pm 0,14\end{array}$ & $\begin{array}{l}1170,80 \\
\pm 893,83\end{array}$ & $\begin{array}{l}1410,36 \\
\pm 197,87\end{array}$ & $\begin{array}{c}0,68 \\
\pm 0,34\end{array}$ \\
\hline Nam & $\begin{array}{c}1962,75 \\
\pm 1475,53\end{array}$ & $\begin{array}{c}-81,42 \\
\pm 105,59\end{array}$ & $\begin{array}{c}4,06 \\
\pm 5,67\end{array}$ & $\begin{array}{c}0,80 \\
\pm 0,28\end{array}$ & $\begin{array}{l}1160,00 \\
\pm 623,80\end{array}$ & $\begin{array}{c}1901,72 \\
\pm 1423,21\end{array}$ & $\begin{array}{c}0,83 \\
\pm 0,55\end{array}$ \\
\hline Onaran & $\begin{array}{c}1749,68 \\
\pm 1585,18\end{array}$ & $\begin{array}{l}-54,74 \\
\pm 95,94\end{array}$ & $\begin{array}{c}3,47 \\
\pm 3,84\end{array}$ & $\begin{array}{c}0,69 \\
\pm 0,15\end{array}$ & $\begin{array}{l}1008,16 \\
\pm 618,67\end{array}$ & $\begin{array}{c}2173,34 \\
\pm 1640,72\end{array}$ & $\begin{array}{c}0,69 \\
\pm 0,31\end{array}$ \\
\hline Ünlenen & $\begin{array}{c}1633,59 \\
\pm 1298,20\end{array}$ & $\begin{array}{l}-59,67 \\
\pm 85,55\end{array}$ & $\begin{array}{c}1,83 \\
\pm 1,96\end{array}$ & $\begin{array}{c}0,69 \\
\pm 0,17\end{array}$ & $\begin{array}{c}995,17 \\
\pm 510,29\end{array}$ & $\begin{array}{c}1440,83 \\
\pm 1312,61\end{array}$ & $\begin{array}{c}0,72 \\
\pm 0,35\end{array}$ \\
\hline \multicolumn{8}{|l|}{$\begin{array}{l}\text { Cooking } \\
\text { method }\end{array}$} \\
\hline Fresh & $\begin{array}{c}1416.08 \\
\pm 322.91^{\mathrm{b}}\end{array}$ & $\begin{array}{c}-20.11 \\
\pm 38.08^{\mathrm{a}}\end{array}$ & $\begin{array}{c}1.08 \\
\pm 0.31^{\mathrm{b}}\end{array}$ & $\begin{array}{c}0.86 \\
\pm 0.017^{\mathrm{a}}\end{array}$ & $\begin{array}{c}1111.00 \\
\pm 212.26^{\mathrm{b}}\end{array}$ & $\begin{array}{c}1070.69 \\
\pm 174.33^{\mathrm{b}}\end{array}$ & $\begin{array}{c}1.24 \\
\pm 0.22^{\mathrm{a}}\end{array}$ \\
\hline Boiled & $\begin{array}{c}4272.66 \\
\pm 512.51^{\mathrm{a}}\end{array}$ & $\begin{array}{l}-192.99 \\
\pm 34.66^{\mathrm{b}}\end{array}$ & $\begin{array}{c}0.54 \\
\pm 0.04^{\mathrm{b}}\end{array}$ & $\begin{array}{c}0.48 \\
\pm 0.036^{\mathrm{c}}\end{array}$ & $\begin{array}{c}2045.50 \\
\pm 235.74^{\mathrm{a}}\end{array}$ & $\begin{array}{c}1124.29 \\
\pm 155.69^{\mathrm{b}}\end{array}$ & $\begin{array}{c}0.35 \\
\pm 0.04^{\mathrm{c}}\end{array}$ \\
\hline $\begin{array}{l}\text { Deep } \\
\text { fried }\end{array}$ & $\begin{array}{c}537.89 \\
\pm 234.78^{c}\end{array}$ & $\begin{array}{c}-8.59 \\
\pm 15.90^{\mathrm{a}}\end{array}$ & $\begin{array}{c}8.03 \\
\pm 3.20^{\mathrm{a}}\end{array}$ & $\begin{array}{c}0.83 \\
\pm 0.035^{\mathrm{a}}\end{array}$ & $\begin{array}{c}442.04 \\
\pm 186.18^{c}\end{array}$ & $\begin{array}{c}3191.95 \\
\pm 1310.61^{\mathrm{a}}\end{array}$ & $\begin{array}{c}0.84 \\
\pm 0.08^{\mathrm{b}}\end{array}$ \\
\hline Pan fried & $\begin{array}{c}1223.86 \\
\pm 609.05^{\mathrm{b}}\end{array}$ & $\begin{array}{l}-35.80 \\
\pm 43.71^{\mathrm{a}}\end{array}$ & $\begin{array}{c}1.99 \\
\pm 1.01^{\mathrm{b}}\end{array}$ & $\begin{array}{c}0.70 \\
\pm 0.017^{\mathrm{b}}\end{array}$ & $\begin{array}{c}819.43 \\
\pm 374.96^{\mathrm{b}}\end{array}$ & $\begin{array}{c}1348.81 \\
\pm 671.22^{\mathrm{b}}\end{array}$ & $\begin{array}{c}0.49 \\
\pm 0.02^{\mathrm{c}}\end{array}$ \\
\hline
\end{tabular}

Data are expressed as means

\pm SD $(\mathrm{n}=5)$. Values in each column having different letter are significantly different $(\mathrm{p}<0,01)$ 
At the same time hardness values were increased when all of the potato varieties boiled. Before the texture analysis, boiled potatoes were cooled down during the preparation of samples so retrogradation of starch molecules may lead to an increase in hardness values. Singh and co-workers [19] concluded that differences between the textural parameters of raw tubers are due to the differences in their microstructure. Also, the resistance created by friction on the texture analyzer's bottom plate against the movement of the potato mass to the right and left in response to the force given to the boiled potato samples is thought to have caused the hardness value to be higher than the other samples. The lowest hardness values observed in deep fried group of potato samples. The highest adhesiveness value was detected in boiled samples while the lowest one was the deep fried samples. According to Table 4 springiness values of potato samples which cooked different methods were significantly different from each other. Cohesiveness of fresh and deep fried samples was significantly different from boiled and pan fried samples. Boiled samples has the highest and deep fried potatoes has the lowest gumminess values. There were no significant differences were found between fresh and pan fried samples. Deep fried potatoes showed the highest chewiness and significantly different from other cooking methods. And there were no significant differences were found between boiling, pan fried and fresh samples. Resilience of fresh samples was found significantly higher than deep fried and deep fried was higher than the other two cooking methods.

Dry matter and starch contents are responsible for the textural and rheological characteristics of raw and cooked tubers [21]. Shetty and co-workers (1992) concluded textural parameter changes are due to the physicochemical and cell wall structure changes. Also during the cooking various factors changes such as gelatinization, degradation of pectin etc. and affects the texture of the cooked potatoes. Nourian and co-workers [10] showed that the texture changes kinetics are due to the cooking of potatoes are functions of cooking temperature and time. Şerban and co-workers [22] showed that the boiling of potato varieties results with an increase in hardness values. According to Marle and co-workers [23]) adhesiveness of potato samples increased as a result of the temperature during cooking. They also concluded that it can be related to starch gelatinization and heated cells become filled with gelatinized starch so diminished the intercellular cohesion. Table 5 shows the significant $(\mathrm{p}<0.01)$ correlations between cooking method and springiness, gumminess, chewiness and resilience. Also, there was significant correlations between dry matter and hardness, springiness, gumminess, chewiness $(\mathrm{p}<0.01)$ and adhesiveness $(\mathrm{p}<0.05)$.

Table 5

Correlations between texture profile parameters and cooking method, dry matter, starch content

\begin{tabular}{|c|c|c|c|c|c|c|c|}
\hline & 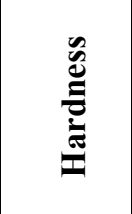 & 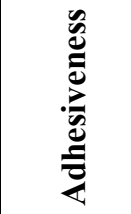 & 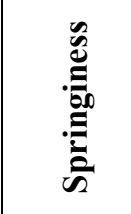 & 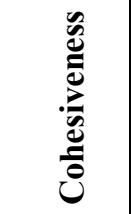 & $\underset{\Xi}{\mathscr{E}}$ & $\underset{0}{\stackrel{0}{0}}$ & 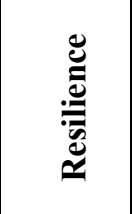 \\
\hline Cooking method & $0,031^{\mathrm{ns}}$ & $-0,168^{\mathrm{ns}}$ & $0,638^{* *}$ & $-0,204^{\mathrm{ns}}$ & $-0,136^{\mathrm{ns}}$ & $0,609^{* *}$ & $-0,409^{* *}$ \\
\hline Dry matter & $-0,566^{* *}$ & $0,394^{*}$ & $0,596^{* *}$ & $0,235^{\mathrm{ns}}$ & $-0,660^{* *}$ & $0,422^{* *}$ & $-0,132^{\mathrm{ns}}$ \\
\hline Starch & $-0,009^{\mathrm{ns}}$ & $-0,024^{\mathrm{ns}}$ & $-0,138^{\mathrm{ns}}$ & $0,111^{\mathrm{ns}}$ & $0,097^{\mathrm{ns}}$ & $0,074^{\mathrm{ns}}$ & $0,492^{* *}$ \\
\hline
\end{tabular}

**; Significant at 0.01 level,*; Significant at 0.05 level ns; Not Significant 


\section{Conclusions}

TPC and antioxidant activities of pan fried samples are significantly higher from other cooking methods. Followed by deep fried examples, but this cooking method increases the calorie of servings. TPC of the samples gave strongest correlations with antioxidant activity analysis and these results support literature information. When compared with fresh and panfried potato samples, the DPPH method revealed 1.3--1.45 times more antioxidant activity, while the ABTS and FRAP methods showed 2.92-4.45 times more activity at the pan-fried samples. The results may also help consumers for choosing the cooking method for health promoting compounds to human use. There is a need for further researches about the bio availability of nutrients from different parts of potatoes and new cultivars.

Acknowledgements. Special thanks to the Potato Research Institute of the Ministry of Agriculture and Forestry of the Turkish Republic for obtaining the new cultivar potatoes.

\section{References}

1. Prokop S., and Albert J. (2008), Potatoes, nutrition and diet, Food Agric Organ Factsheet, pp.1-2.

2. Ezekiel R., Singh N., Sharma S., Kaur A. (2013), Beneficial phytochemicals in potato - a review, Food Res Int, 50, pp. 487-496.

3. Tierno R., Hornero-Méndez D., Gallardo-Guerrero L., López-Pardo R., Galarreta J.I.R. (2015), Effect of boiling on the total phenolic, anthocyanin and carotenoid concentrations of potato tubers from selected cultivars and introgressed breeding lines from native potato species, J Food Compos Anal, 41, pp. 58-65.

4. Palermo M., Pellegrini N., Fogliano V. (2014), The effect of cooking on the phytochemical content of vegetables, J Sci Food Agric 94, pp.1057-1070.

5. Shahidi F., Chavan U.D., Naczk M., Amarowicz R. (2001), Nutrient distribution and phenolic antioxidants in air-classified fractions of beach pea (Lathyrus maritumus L.), J Agric Food Chem, 49, pp. 926-933.

6. Kaur C., Kapoor H.C. (2002), Anti-oxidant activity and total phenolic content of some Asian vegetables, Int J Food Sci Technol, 37, pp. 153-161.

7. Kasnak C. (2020), Effects of Anti-browning Treatments on the Polyphenol Oxidase and Antioxidant Activity of Fresh-Cut Potatoes by Using Response Surface Methodology, Potato Res, 63, pp. 417-430.

8. Re R., Pellegrini N., Proteggente A., Pannala A., Yang M., Rice-Evans C. (1999), Antioxidant Activity Applying an Improved Abts Radical Cation Decolorization Assay, Free Radic Biol Med, 26, pp. 1231-1237.

9. Benzie I.F.F., Strain J.J. (1996), The Ferric Reducing Ability of Plasma ( FRAP ) as a Measure of "Antioxidant Power": The FRAP Assay, Anal Biochem, 76, pp. 70-76.

10. Nourian F., Ramaswamy H.S., Kushalappa A.C. (2003), Kinetic changes in cooking quality of potatoes stored at different temperatures. J Food Eng 60, pp. 257-266.

11. Karadeniz F., Burdurlu H.S., Koca N., Soyer Y. (2005), Antioxidant Activity of Selected Fruits and Vegetables Grown in Turkey, Turk J Agric, 29, pp. 297-303.

12. Lachman J., Hamouz K., Orsak M., Pivec V., Dvorak P. (2008The influence of flesh colour and growing locality on polyphenolic content and antioxidant activity in potatoes, Sci Hortic (Amsterdam) 117, pp.109-114). 
13. Perla V., Holm D.G., Jayanty S.S. (2012), Effects of cooking methods on polyphenols, pigments and antioxidant activity in potato tubers, LWT - Food Sci Technol, 45, pp. 161-171.

14. Blessington T., Nzaramba M.N., Scheuring D.C., Hale A.L., Reddivari L., Jr J.C.M. (2010), Cooking Methods and Storage Treatments of Potato : Effects on Carotenoids, Antioxidant Activity, and Phenolics, Am J Potato Res, 87, pp. 479-491.

15. Rumbaoa R.G.O., Cornago D.F., Geronimo I.M. (2009), Phenolic content and antioxidant capacity of Philippine potato (Solanum tuberosum) tubers, $J$ Food Compos Anal, 22, pp. 546-550.

16. Bellumori M., Innocenti M., Michelozzi M., Cerretani L., Mulinacci N. (2017), Coloured-fleshed potatoes after boiling: Promising sources of known antioxidant compounds, J Food Compos Anal, 59, pp. 1-7.

17. Bellail A.A., Shaltout O.E., Youssef M.M., and Gamal A.M.A. El. (2012), Effect of Home-Cooking Methods on Phenolic Composition and Antioxidant Activity of Sweetpotato ( Ipomoea batatas ( L .) Lam .) Cultivars Grown in Egypt, Food Nutr Sci, pp. 490-499.

18. Deng G-F., Lin X., Xu X-R., Gao L-L., Xie J-F., Li H-B. (2013), Antioxidant capacities and total phenolic contents of 56 vegetables, J Funct Foods, 5, pp. 260-266.

19. Singh N., Kaur L., Ezekiel R., Guraya H.S., (2005), Microstructural, cooking and textural characteristics of potato (Solanum tuberosum L) tubers in relation to physicochemical and functional properties of their flours, J Sci Food Agric, 85, pp.1275-1284.

20. Pedreschi F., Moyano P., Kaack K., Granby K. (2005), Color changes and acrylamide formation in fried potato slices, Food Res Int, 38, pp.1-9.

21. Singh J., Kaur L., McCarthy O.J., Moughan P.J., Singh H. (2008), Rheological and textural characteristics of raw and par-cooked Taewa (maori potatoes) of New Zealand, $J$ Texture Stud 39, pp.210-230.

22. Şerban A.M., Trifan M., Nistor O., Andronoiu D.G., Mocanu G.D., Botez E. (2014), Effects Of Bolling On Physico-Chemıcal Properties, Texture And Quality Of Potatoes, Agric - Ştiinţă şi Pract, 2, pp. 41-48.

23. Marle J.T. Van, Clerkx A.C.M., Boekestein A. (1992), Cryo-Scanning Electron Microscopy Investigation of the Texture of Cooked Potatoes, Food Struct, 11, pp. 209 216. 